\title{
HOAX DALAM PERSPEKTIF ISLAM
}

\author{
Takdir Alisyahbana
}

STAI Bumi Silampari Lubuklinggau

takdiralisyahbana@staibsllg.ac.id

\begin{tabular}{|c|c|}
\hline Abstrak & \\
\hline $\begin{array}{l}\text { Article History } \\
\text { Received :05-09-2019 } \\
\text { Revised : 06-09-2019 } \\
\text { Accepted: 25-09-2019 }\end{array}$ & $\begin{array}{l}\text { Hoax becomes very popular when } \\
\text { information technology makes it } \\
\text { easy for all social media circles } \\
\text { through internet devices either via }\end{array}$ \\
\hline $\begin{array}{l}\text { Keywords : } \\
\text { Hoaxes, } \\
\text { Islamic perspective, } \\
\text { Information revolution }\end{array}$ & $\begin{array}{l}\text { compiuter or Android mobile. The } \\
\text { use of social media for hoax news, } \\
\text { can have a negative impact on the } \\
\text { morality of the nation's children. } \\
\text { The teachings of Islam strongly } \\
\text { prohibit humans from spreading } \\
\text { false news either through oral or } \\
\text { written. Therefore to combat Islamic } \\
\text { hoaxes provide accurate solutions, } \\
\text { in the form of communication } \\
\text { principles. }\end{array}$ \\
\hline
\end{tabular}

\section{Pendahuluan}

Informasi bagian penting dari kehidupan manusia, yang dibentuk oleh kebutuhan manusia dalam berinteraksi baik dalam hal ritual (ibadah), sosial maupun ilmu pengetahuan dan teknologi. Dalam dunia konvensional informasi didapat melalui lisan dan tulisan kondisi tersebut mendominasi kehidupan manusia pra modern. Kondisi tersebut berubah total setelah manusia menemukan teknologi informasi, yang dimulai penemuan gelombang radio, telegraf, telepon, televisi, internet dan Handphone. Penemuan piranti komunikasi merubah dunia informasi konvensional menjadi revolusi teknologi informasi, yang mengubah dunia informasi menjadi revolusi teknologi informasi dan mempermudah untuk mendapatkan informasi sebagai yang diungkapkan oleh (Asep Wahyudin, 2017:24) Revolusi teknologi informasi telah 
mempermudah manusia untuk mengekses dunia maya dimanapun dan kapanpun melalui media internet. Keniscayaan internet yang bersentuhan dunia maya merupakan bagian revolusi teknologi yang bisa berdampak dan bermata ganda baik dan buruk. Komunikasi, Revolusi teknologi informasi telah mengubah gaya komunikasi manusia secara radikal dalam wujud media sosial dan menjadi identitas komunikasi masa kini, sebagai yang diungkapkan oleh (Muhammad Zamroni, 2019:69) hadirnya media sosial sebagai media konvergen tidak dapat dibendung karena bagian dari revolusi komunikasi. Media sosial telah menjadi identitas masyarakat modern yang menjanjikan berbagai kemudahan dalam berkomunikasi, memperoleh informasi dan berbagai perubahan baik perubahan teknologi, gaya hidup maupun isuisu sosial di masuarakat.

Internet ketika bersentuhan dengan dunia maya akan memberikan dampak baik dan buruk. Di Indonesia menurut (Asep Wahyudi, 2019:26) perkembangan internet begitu pesat dan begitu pula dampak-dampaknya terjadi, di antaranya hoax, yang berkembang begitu dahsyat. Data dari Kementerian Komunikasi dan Informasi, pada tahun 2012 terdapat 800 ribu situs di Indonesia penyebar hoax. Dan terus berkembang, di tahun 2016 dan 2017 ketika PILKADA DKI Jakarta berita hoax meningkat tajam. Kegiatan berita hoax telah membuat keuntungan besar bagi pembuat situs, dan kerugian besar bagi pembaca situsnya.

Fenomena hoax yang marak terjadi di abad milenium ini, terlebih pada media sosial, telah meracuni pikiran dan membawa dampak negatif bagi masyarakat. Ditambah lagi,Indonesia menduduki peringkat keenam sebagai negara dengan pengguna internet terbesar di dunia dan dapat dipastikan mayoritas pengguna media sosial dan terkena dampaknya adalah umat Islam. karena dampak negatifnya begitu masif bagi kehidupan sosial masyarakat, menarik perhatian penulis untuk mengkaji HOAX dari perspektif Islam. 


\section{Metode Penelitian}

Dalam penelitian ini menggunakan metode kajian literatur dengan mencari referensi teori yang relevan dengan kasus atau permasalahan yang ditemukan. Berdasarkan Pendapat (Creswell, John. W, 2014; 40) bahwa kajian literatur adalah ringkasan tertulis mengenai artikel dari jurnal, buku, dan dokumen lain yang mendeskripsikan teori serta informasi baik masa lalu maupun saat ini mengorganisasikan pustaka ke dalam topik dan dokumen yang dibutuhkan. Maka dalam hal ini penulis menggunakan jenis data yang diperoleh dari studi literatur atau menghimpun data-data atau sumbersumber yang berhubungan dengan topik yang diangkat dalam penelitian. Dalam hal ini mengkaji hoax dalam perspektif pendidikan Islam.

\section{Pembahasan}

Hoax $=($ Inggris $)$ artinya tipuan, menipu, berita bohong, berita palsu atau kabar burung. Berita bohong adalah berita yang isinya tidak sesuai dengan kebenaran yang sesungguhnya (materiële waarheid). Jadi dapat dikatakan bahwa Hoax adalah kata yang berarti ketidak benaran suatu informasi. Hoax bukan singkatan tetapi satu kata dalam bahasa inggris yang punya arti sendiri. Sedangkan definisi Hoax menurut wikipedia adalah: "Sebuah pemberitaan palsu adalah usaha untuk menipu atau mengakali pembaca/pendengarnya untuk mempercayai sesuatu, padahal sang pencipta berita palsu tersebut tahu bahwa berita tersebut palsu (https://id.wikipedia. org/wiki/Pemberitaan_palsu diakses jam 23.22 WIB tgl 5/01/2018). Definisi tersebut dipertegas oleh Mukti Ali (2019:106) Hoax adalah suatu kejadian yang dibuat-buat, berita bohong, tidak sesuai dengan kenyataan, karena kurangnya informasi, pengetahuan, akhirnya digembar gemborkan seolah-olah berita itu benar, pada hal tidak benar.

Definisi di atas mengaskan bahwa hoax informasi palsu yang sengaja diproduk untuk membangun opini untuk mendapatkan keuntungan tertentu, melalui saluran media sosial.

Jenis-jenis Informasi Hoax

Informasi Hoax yang dibuat oleh Hokker beragam, Ded Rianto Rahadi membaginya tujuh jenis sebagai berikut: 
a. Fake news: Berita bohong: Berita yang berusaha menggantikan berita yang asli. Berita ini bertujuan untuk memalsukan atau memasukkan ketidakbenaran dalam suatu berita.

b. Clickbait: Tautan jebakan: Tautan yang diletakkan secara stategis di dalam suatu situs dengan tujuan untuk menarik orang masuk ke situs lainnya.

c. bias: Bias konfirmasi: Kecenderungan untuk menginterpretasikan kejadian yang baru terjadi sebaik bukti dari kepercayaan yang sudah ada.

d. Misinformation: Informasi yang salah atau tidak akurat, terutama yang ditujukan untuk menipu.

e. Satire: Sebuah tulisan yang menggunakan humor, ironi, hal yang dibesar-besarkan untuk mengkomentari kejadian yang sedang hangat. Berita satir dapat dijumpai di pertunjukan televisi seperti "Saturday Night Live" dan "This Hour has 22 Minutes".

f. Post-truth: Pasca-kebenaran: Kejadian di mana emosi lebih berperan daripada fakta untuk membentuk opini publik.

g. Propaganda: Aktifitas menyebar luaskaninformasi, fakta, argumen, gosip, setengah kebenaran, atau bahkan kebohongan untuk mempengaruhi opini publik. (Dedi Rianto Rahadi, perilaku penggunaan dan informasi hoax di media social, jurmal manajemen \& kewiraushaan vol 5 no 12017 (MALANG: JMDK, 2017)

\section{Hoax Dalam Lintasan Sejarah}

Secara historis Hoax telah digunakan sebelum munculkan revolusi informasi. Dalam kitab suci Al-Qur'an hoax menjadi instrumen vital dalam menjerumuskan Nabi Adam dan isterinya melanggar larangan Allah SWT, untuk tidak memakan buah huldi. Adam dan isterinya diperdaya oleh informasi hoax Iblis, yang mengatakan larangan Allah tersebut menurut versi Iblis agar Adam dan isterinya tidak kekal dalam Surga (Q.S.20:120). Adam dan isterinya terpropokasi oleh berita hoax yang diproduk oleh Iblis (Q.S.20:121).

Hoax dialami juga oleh para Nabi termasuk Nabi Muhammad saw. Banyak sekali berita-berita hoax yang diproduk oleh kafir Qureisy dan kaum Yahudi, yang paling 
populer adalah berita Hoax tentang peristiwa haditsul ifqi. Menurut Saipul Amin (https://news.detik.com/kolom/d3387431/hoax-dari-era-nabi-muhammad-hingga-medsos)

Fenomena perilaku hoax bukanlah hal baru, sejarah dunia pun banyak diisi oleh cerita-cerita yang terbukti hoax di kemudian hari. Dunia sains, dunia militer bahkan dalam urusan agama sekali pun terdapat banyak berita hoax yang bertebaran dari masa ke masa. Dari hoax serius yang mempertaruhkan dan bahkan mengorbankan berjuta-juta yawa hingga percuma hoax sepele yang sekedar menggelikan para pembaca atau pendengar sebuah cerita. Lucunya, ada hoax menggelikan yang terkadang bisa memicu peperangan antar bangsa.

Maraknya berita hoax yang akhir-akhir ini melanda dunia media sosial (medsos) kita bukanlah hal baru. Dalam Islam, berita hoax bahkan sudah terjadi sejak zaman Nabi Muhammad SAW masih hidup. Suasana peperangan yang tidak pasti sering menjadikan berita-berita beterbangan lebih cepat nyaring dari denting pedang dan lebih cepat dari anak panah melesat meninggalkan busurnya. Padahal zaman dulu paling cepat juga orang hanya bisa naik kuda, nggak mungkin juga toh naik anak panah? Apalagi menyalip hoax. Contoh berita hoax lainnya yang pernah terjadi dalam sejarah Islam adalah berita tentang tewasnya Sahabat Nabi yang bernama Utsman bin Affan. Saat itu, di tahun keenam Hijriyah, Nabi Muhammad SAW menerima perintah perjalanan umrah. Nabi pun bertolak bersama sekitar 1400-an sahabatnya dari Madinah. Perjalanan ini bukan tanpa tantangan, berombongan di padang pasir melewati beberapa tempat berbahaya dan persimpangan yang biasa dijadikan lahan pembegalan besarbesaran.

Perjalanan yang panjang di medan gurun membuat seringkali membuat para sahabat hampir-hampir tak kuasa menahan amarah. Perjalanan umrah yang semestinya bertujuan damai pun hampir-hampir diwarnai oleh beberapa pertumpahan darah. Beberapa sahabat mengusulkan kepada Nabi untuk melawan penghadangan-penghadangan dan gangguan-gangguan di perjalanan ibadah mereka. Beberapa orang menghadap Nabi meminta izin untuk melakukan 
tindakan kekerasan atau tindakan militer. Nggak kebayang kan bagaimana jadinya bila 1400 -an orang diizinkan membalas? untung ada seorang sahabat yang sangat bijak bernama Abu bakar yang selalu mengingatkan Nabi, "Ya Rasulullah, engkau keluar untuk melaksanakan umrah, bukan untuk memerangi siapapun. Maka fokuslah untuk itu. Siapa pun yang mencoba menghalangi untuk melasanakan ibadah umroh dan berkeinginan merusak keinginan tersebut, maka baru kita perangi mereka."Nabi bahkan terpaksa mengubah jalur untuk menghindari pertempuran dan penghadangan dari orang Makkah dan sekutu-sekutu sang kafir Quraisy. Rasulullah berusaha keras agar kedatangannya bersama rombongan ke Makkah dapat diterima dengan baik, bahwa kedatangan mereka bukan untuk berperang. Rasulullah berunding dengan perwakilan Quraisy yang menghadangnya di dekat kota Makkah dan mengutus beberapa orang yang dipimpin sahabat Utsman untuk berunding dengan para pemimpin Quraisy di pusat kota Makkah. Pada saat-saat genting tidak menentu inilah kabar hoax itu bermula di antara kaum Muslimin. Beredar hoax yang entah diproduksi di mana, bahwa sahabat Utsman telah tewas. Memang utusan sebelum Utsman bernama Khirasy bin Umayyah al-Khuzai telah ditolak dan onta Nabi yang ditungganginya dibunuh. Masih untung penunggangnya dibiarkan pergi. Pengalaman inilah yang membuat rombongan galau tingkat dewa.

Mungkin berdasar hal itu, kepergian Utsman yang cukup lama lalu memunculkan ketidakpastian di hati para sahabat Nabi, hingga mereka pun mudah termakan hoax. Padahal justru sahabat Utsman diterima baik oleh Quraisy Makkah dan bahkan diizinkan untuk melaksanakan ibadah umrah. Akan tetapi Sahabat Utsman menolaknya dengan halus, beliau nggak enak dengan kawan-kawannya, khususnya dengan Nabi yang belum berhasil umrah dalam misi tersebut. Menyikapi hoax yang semakin memanas ini, Nabi mengambil inisiatif untuk merapatkan barisan. Nabi meminta janji setia kepada para sahabatnya. Di mana inti janji setia ini sungguh sangat memberatkan para pengikut Nabi Muhammad SAW yang berbunyi, "Siapa saja yang datang ke Madinah dari kota Makkah harus di kembalikan ke kota Makkah. Siapa saja dari 
penduduk Madinah yang datang ke Makkah, maka tidak boleh dikembalikan ke Madinah." Duh, kayaknya nggak adil kan?

Meski begitu para sahabat tetap patuh, mereka setia pada janji untuk tetap saling menguatkan, bukan saling menjatuhkan. Tetapi lihatlah saat ini, saat para ulama sebagai para pewaris Nabi berbeda pendapat, yang kita lihat dan dengar, tidak jarang muncul ungkapan saling menjatuhkan. Celakanya, masing-masing yang berbeda pendapat ini, kita melihat banyak pengikut yang ceroboh. Mereka sibuk dan sangat bersemangat untuk saling serang dan saling menjatuhkan.

Parahnya, saat ini hoax menjadi senjata utama dalam aktifitas para pengikut ini. Hoax menjadi amunisi kekinian yang ditembakkan lewat beragam aplikasi sosial media yang kecepatannya melebihi jet-jet tempur Amerika dan Rusia sekalipun. Lalu akankah kita berharap umat Islam menjadi pemenang dalam percaturan dunia, bila para pengikutnya justru terlibat perang dan saling fitnah? Tentu tidak, dan oleh karena itu kita harus mengakhiri era hoax ini. Kita harus menjadi pribadi yang bijak yang saling menguatkan sesama saudara seiman.

Nabi Muhammad Shallalahu Alaihi Wasallam dan keluarganya pernah menjadi korban HOAX, ketika isteri beliau, Aisyah Radliyallahu Anha, dituduh selingkuh, dan beritanya menjadi 'viral' di Madinah. Peristiwa itu dalam sejarah dinamakan hadits al-Ifki. Berita bohong ini menimpa istri Rasulullah Shallalahu Alaihi Wasallam 'Aisyah Radliyallahu Anha. Ummul Mu'minin, setelah perang dengan Bani Mushtaliq pada bulan Sya'ban 5 H. Peperangan ini diikuti kaum munafik, dan turut pula 'Aisyah dengan Nabi berdasarkan undian yang diadakan antara istri-istri beliau. Dalam perjalanan mereka kembali dari peperangan, mereka berhenti pada suatu tempat. 'Aisyah keluar dari sekedupnya untuk suatu keperluan, kemudian kembali. Tiba-tiba dia merasa kalungnya hilang, lalu dia pergi lagi mencarinya. Sementara itu, rombongan berangkat dengan persangkaan bahwa 'Aisyah masih ada dalam sekedup. Setelah 'Aisyah mengetahui, sekedupnya sudah berangkat dia duduk di tempatnya dan mengaharapkan sekedup itu akan kembali 
menjemputnya. Kebetulan, lewat di tempat itu seorang sahabat Nabi, Shafwan bin Mu'aththal, diketemukannya seseorang sedang tidur sendirian dan dia terkejut seraya mengucapkan: "Inna lillahi wa inna ilaihi raji'un, isteri Rasul!" 'Aisyah terbangun. Lalu dia dipersilahkan oleh Shafwan mengendarai untanya. Syafwan berjalan menuntun unta sampai mereka tiba di Madinah. Orang-orang yang melihat mereka membicarakannya menurut pendapat masing-masing. Mulailah timbul desas-desus. Kemudian kaum munafik membesarkannya, maka fitnahan atas 'Aisyah Radliyallahu Anha. itu pun bertambah luas, sehingga menimbulkan kegoncangan di kalangan kaum Muslimin. Akhirnya Allah mengklarifikasi berita itu, dengan menurunkan firman-Nya dalam Al-Quran Surat An-Nur (24): 12

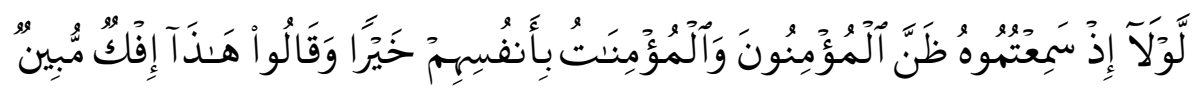

Terjemahan: Mengapa di waktu kamu mendengar berita bohon itu orang-orang mukminin dan mukminat tidak bersangka baik terhadap diri mereka sendiri, dan (mengapa tidak) berkata: "Ini adalah suatu berita bohong yang nyata." (Q.S. An-Nur[24]:12)

Khalifah Utsman bin Affan tewas ditikam seorang penghafal Al-Quran yang termakan hoax (fitnah) bahwa sang khalifah melakukan korupsi, kolusi, dan nepotisme. Peristiwa penikaman ini terjadi pada bulan Dzulhijjah tahun $35 \mathrm{H} . / 656$ M. Nama pelakunya Al-Ghafiqi. Khalifah Ali bin Abi Thalib dibunuh kelompok Khawarij, yang memfitnahnya sebagai penista hukum Al-Quran karena ingin damai dengan Muawiyah bin Abi Sufyan, meninggalkan hukum Allah dan melakukan tahkim (arbitrase). Hoax yang disebarkan dan kemudian dipegangi Khawarij, Sayyidina Ali dan Muawiyah tidak mengamalkan perintah (hukum) Allah, dan harus dibunuh (Dalam Al-Quran Surat Al-Maidah:44). 


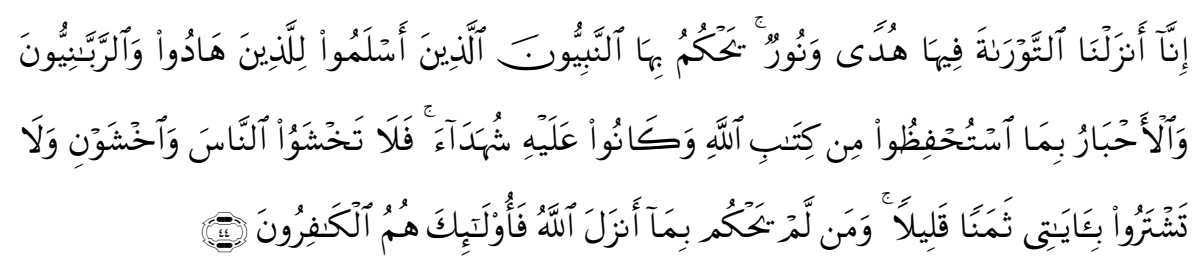

Terjemahan: Sesungguhnya Kami telah menurunkan kitab Taurat di dalamnya (ada) petunjuk dan cahaya (yang menerangi), yang dengan kitab itu diputuskan perkara orang-orang Yahudi oleh nabi-nabi yang menyerah diri kepada Allah, oleh orang-orang alim mereka dan pendeta-pendeta mereka, disebabkan mereka diperintahkan memelihara Kitab-Kitab Allah dan mereka menjadi saksi terhadapnya. karena itu janganlah kamu takut kepada manusia, (tetapi) takutlah kepada-Ku. dan janganlah kamu menukar ayat-ayat$\mathrm{Ku}$ dengan harga yang sedikit. Barangsiapa yang tidak memutuskan menurut apa yang diturunkan Allah, Maka mereka itu adalah orangorang yang kafir.

Periode berikutnya, banyak kabar hoax berupa ceritacerita Israiliyat, yang mengaburkan sejarah, baik dalam kitab tafsir, syarah hadis, maupun kitab Fiqih dan Ahlak-Tasawuf. Sejarah hoax Meski baru mengambil peran utama dalam panggung diskusi publik Indonesia di beberapa dekade terakhir ini, hoaks sebetulnya punya akar sejarah yang panjang. Hoaks yang kini tercantum di Kamus Besar Bahasa Indonesia dengan arti "berita bohong" tak sesederhana kelihatannya. Sebuah kebohongan bisa disebut hoaks apabila dibuat secara sengaja agar dipercaya sebagai sebuah kebenaran. Tak hanya itu, kebohongan baru bisa (Chazawi adami dan ferdian ardi, Tindak pidana pemalsuan, (Jakarta : PT Raja grafindo persada, 2016: hal: 236 https://id.wikipedia.org/wiki/Pemberitaan_palsu diakses jam 23.22 WIB tgl 5/01/2018 disebut hoaks apabila keberadaannya memiliki tujuan tertentu, seperti misalnya untuk memengaruhi opini publik. Menurut Lynda Walsh dalam buku berjudul Sins Against Science, istilah hoax atau kabar bohong, merupakan istilah dalam bahasa Inggris yang masuk sejak era industri. Diperkirakan pertama kali muncul pada 1808.3 Menurut Alexander Boese dalam bukunya, Museum of Hoaxes, mencatat hoax pertama yang dipublikasikan adalah almanak 
atau penanggalan palsu yang dibuat Isaac Bickerstaff alias Jonathan Swift pada 1709. Saat itu, ia meramalkan kematian astrolog John Partridge.

Agar meyakinkan publik, ia bahkan membuat obituari palsu tentang Partridge pada hari yang diramal sebagai hari kematiannya. Swift mengarang informasi tersebut untuk mempermalukan Partridge di mata publik. Partridge pun berhenti membuat almanak astrologi hingga 6 tahun setelah hoax beredar. Di luar rumor, kabar burung, dan desas-desus yang jelas berusia lebih tua lagi, hoaks pertama yang berhasil dicatat sejarah ditemui pada 1661. Kasus tersebut adalah soal Drummer of Tedworth, yang berkisah soal John Mompesson seorang tuan tanah- yang dihantui oleh suara-suara drum setiap malam di rumahnya. Ia mendapat nasib tersebut setelah ia menuntut William Drury -seorang drummer band gipsydan berhasil memenangkan perkara. Mompesson menuduh Drury melakukan guna-guna terhadap rumahnya karena dendam akibat kekalahannya di pengadilan. Singkat cerita, seorang penulis bernama Glanvill mendengar kisah tersebut. Ia mendatangi rumah tersebut dan 3 Lynda Walsh (2016), Sins Against Science,,. http://www.sunypress.edu/p-4327- sinsagainst-science.aspx diakses jam 16.45 WIB tgl 28-12-2017 4 Yudo Triartanto, Kredibilitas Teks Hoax Di Media Siber. Jurnal komunikasi volume VI no 2 (Jakarta: Akademi Komunikasi BSI, 2015) hal 34 mengaku mendengar suarasuara yang sama. Ia kemudian menceritakannya ke dalam tiga buku cerita yang diakunya berasal dari kisah nyata.5 Kehebohan dan keseraman local horror story tersebut berhasil menaikkan penjualan buku Glancill. Namun, pada buku ketiga Glanvill mengakui bahwa suara-suara tersebut hanyalah trik dan apa yang di ceritakan adalah bohong belaka.

Ada juga kisah soal Benjamin Franklin yang pada tahun 1745 lewat harian Pennsylvania Gazette mengungkap adanya sebuah benda bernama "Batu China" yang dapat mengobati rabies, kanker, dan penyakit-penyakit lainnya. Sayangnya, nama Benjamin Franklin saat itu membuat standar verifikasi kedokteran tidak dilakukan sebagaimana standar semestinya. Meski begitu, ternyata batu yang dimaksud hanyalah terbuat dari tanduk rusa biasa yang tak memiliki 
fungsi medis apapun. Hal tersebut diketahui oleh salah seorang pembaca harian Pennsylvania Gazette yang membuktikan tulisan Benjamin Franklin tersebut. Hoaks-hoaks senada beberapa kali terjadi sampai adanya Badan Makanan dan Obat-obatan Amerika Serikat pada awal abad 20. Meskipun demikian, kata hoaks sendiri baru mulai digunakan sekitar tahun 1808. Kata tersebut dipercaya datang dari hocus yang berarti untuk mengelabui. Kata-kata hocus sendiri merupakan penyingkatan dari hocus pocus, semacam mantra yang kerap digunakan dalam pertunjukan sulap saat akan terjadi sebuah punch line dalam pertunjukan mereka di panggung. Hingga kini, eksistensi hoaks terus meningkat. Dari kabar palsu seperti entitas raksasa seperti Loch Ness, tembok China yang terlihat dari luar angkasa, hingga ribuan hoaks yang bertebaran di pemilihan umum presiden Amerika Serikat di tahun 2016. Semua hoaks tersebut punya tujuan masing-masing, dari sesederhana publisitas diri hingga tujuan yang amat genting seperti politik praktis sebuah negara adidaya. 5 https://m.kumparan.com/@kumparantech/sejarah-hoaks-danandilnya-dari-masa-ke masa diakses jam 09.30 wib tgl 05-012018 Kemunculan internet semakin memperparah sirkulasi hoaks di dunia. Sama seperti meme, keberadaannya sangat mudah menyebar lewat media-media sosial.

Apalagi biasanya konten hoaks memiliki isu yang tengah ramai di masyarakat dan menghebohkan, yang membuatnya sangat mudah memancing orang membagikannya. Teknologi makin maju, begitu pula dengan hoax. Jika dulunya hoax hanya berkembang lewat buku atau dari mulut ke mulut, kini hoax mulai menjamah internet. Hoax di internet pertama kali muncul pada 1 April 1984, dengan kabar bahwa bekas negara Uni Soviet akan bergabung dalam jaringan Usenet di AS. Berita bohong itu menyebar di banyak website, juga di forum-forum internet. Ajaibnya, sejak itu sering kali muncul hoax (berita palsu) di internet setiap tanggal 1 April, sehingga banyak kalangan yang kemudian menyimpulkan bahwa hoax adalah bagian dari April Mop. Di Indonesia, tidak ada yang tahu berita hoax apa yang pertama kali muncul. Namun, fenomena hoax ini mulai ramai sejak pemilihan gubernur (Pilgub) Jakarta pada tahun 2012 lalu. 
Biasanya berita hoax pada masa ini banyak memberitakan mengenai kejelekan masing-masing cagub, atau istilahnya Black Campaign. Hal ini juga terus berlanjut, bahkan makin menjadi-jadi pada Pilpres 2014 lalu. Setelah tahu apa itu hoax, bagaimana dengan penyebarannya? Penyebaran hoax dipercaya berawal saat perilisan film "The Hoax" pada tahun 2006. Sebelum difilmkan, "The Hoax" muncul dalam bentuk novel. Namun, versi film ternyata berbeda jauh dengan versi novelnya, seperti misalnya ada yang dihilangkan atau diubah. Dari situ, film The Hoax dianggap sebagai film yang banyak $\begin{array}{ll}\text { mengandung } & \text { kebohongan, } \\ \text { https://m.kumparan.com/@kumparantech/sejarah-hoaks-dan- }\end{array}$ 6 andilnya-dari-masa-ke-masa diakses jam 09.30 wib tgl 05-012018 kemudian banyak kalangan terutama para netter yang menggunakan istilah hoax untuk menggambarkan suatu kebohongan.7 https://jadiberita.com/103077/asal-mula-hoaxdan-penyebarannya.html diakses jam 12.00 tgl 30-01- 2018

Fenomena Hoax Hoax atau informasi bohong menjadi fenomena diindonesia hal ini tak luput dari karakteristik masyarakat Indonesia saat ini umumnya senang berbagi informasi dari, sedikitnya 170 juta masyarakat Indonesia memiliki minimal satu ponsel atau setidaknya satu SIM card. Dengan demikian, mereka bisa berbagi informasi dengan cepat. Media sosial dan aplikasi pengirim pesat cepat (chat apps) menjadi media favorit. Sementara Guru besar Ilmu Komunikasi Universitas Padjajaran, Bandung, Deddy Mulyana, menyebut ada faktor utama yang menyebabkan informasi palsu (hoax) mudah tersebarnya di Indonesia.

Faktor itu yakni karakter asli masyarakat Indonesia yang dinilai tidak terbiasa berbeda pendapat atau berdemokrasi secara sehat. Kondisi itu merupakan salah satu faktor mudahnya masyarakat menelan hoax yang disebarkan secara sengaja. "Sejak dulu orang Indonesia suka berkumpul dan bercerita. Sayangnya, apa yang dibicarakan belum tentu benar. Sebab budaya kolektivisme ini tidak diiringi dengan kemampuan mengolah data. Kebanyakan masyarakat tidak terbiasa mencatat dan menyimpan data sehingga sering berbicara tanpa data. Di sisi lain, ia menyebut masyarakat lebih senang membahas aspek-aspek yang berkaitan dengan 
kekerasan, sensualitas, drama, intrik dan misteri. "Politik adalah bidang yang memiliki aspek-aspek tersebut. Sehingga hoax sering sekali terjadi pada tema politik. Khususnya saat terjadi perebutan kekuasaan yang menjatuhkan lawan seperti pilkada, sebagai contoh Terjadi tren peningkatan hoax menjelang Pemilihan Kepala Daerah (Pilkada) DKI Jakarta 2017, namun tren tersebut akan menurun setelah Pilkada usai. 7https://jadi berita. com/ 103077/ asal- mula- hoax- dan penyebarannya. html diakses jam 12.00 tgl 30-01- 2018.

Selanjutya berdasarkan hasil riset yang dilakaukan Mastel (Masyratakat Telematika Indonesia), hasilnya menunjukkan isu politik dan SARA merupakan hal yang paling sering diangkat menjadi materi untuk konten hoax. Isu sensitif soal sosial, politik, lalu suku, agama, ras, dan antar golongan, dimanfaatkan responden mengaku paling sering menerima konten hoax tentang sosial politik, seperti pemilihan kepala daerah dan pemerintahan. Tidak beda jauh dengan sosial politik, isu berada di posisi kedua dengan angka 88,6 persen. Bentuk konten hoax yang paling banyak diterima responden adalah teks sebanyak 62,1 persen, sementara sisanya dalam bentuk gambar sebanyak 37,5 persen, dan video 0,4 persen. Sebanyak 92,4 responden menyatakan mendapatkan konten hoax melalui media sosial, media sosial tersebut adalah Facebook, Twitter, Instagram, dan Path. Angka ini cukup jauh jika dibandingkan dengan situs web (34,9 persen), televisi (8,7 persen), media cetak (5 persen), email (3,1 persen), dan radio (1,2 persen). Hal ini disebabkan karena masyarakat menyukai hal-hal menghebohkan. Hal ini pada dasarnya sangat berbahaya, karena hal ini bisa menjadi perilaku. Pengguna media sosial bisa memproduksi hoax agar bias menimbulkan kehebohan. Selanjutnya Kristiono, memaparkan pada dasarnya sudah banyak masyarakat penerima hoax yang tidak percaya begitu saja dan mengecek kebenarannya terlebih dahulu, namun sebagian di antaranya masih mengalami kesulitan dalam mencari referensi. Dan hingga saat informasi dari kepolisian menyatakan, Polisi sudah menerima sedikitnya 40 ribu laporan berita abal-abal alias hoax yang selama ini tersebar di media sosial. Menurut 
laporan, sekitar 18 ribu di antaranya sudah direspon tim Cyber Crime Mabes Polri dan seribu di antaranya berhasil diproses secara hukum hal ini diungkapkan oleh Kabag Mitra Biro Penmas Mabes Polri Kombes Awi Setyono saat menghadiri pelantikan Ikatan Sarjanan Muda NU Jombang di GOR Pesantren Tambak Beras, Awi menjelaskan, dari jumlah tersebut berita bohong yang paling banyak disebar adalah kasus pornografi dan isu penculikan anak yang akhir-akhir ini cukup meresahkan masyarakat. "Terakhir marak terkait kasus hoax masalah penculikan, itu juga kita luruskan. Karena memang beberapa kasus fakta-fakta hukumnya memang bukti permulaannya enggak cukup, makanya kita sampaikan memang itu hoax. Seperti kasus di Trenggalek, Sumenep, Jawa Timur, ini memang betul faktanya hoax.

Perkembangan teknologi yang sangat pesat ini banyak mempengaruhi kehidupan masyarakat khususnya di Indonesia. Dahulu untuk mencari informasi, masyarakat bisa mendapatkannya melalui media konvensional radio, koran dan televisi. Namun kini hanya dengan bermodalkan smartphone sangat banyak informasi yang bisa didapatkan masyarakat dengan mengakses portal media online atau sharing dan bersosialisasi melalui media sosial. Media menurut Association for Educational Communications and Technology (AECT, 1997) adalah segala bentuk dan saluran yang digunakan untuk menyampaikan pesan atau informasi.

Secara garis besar, dilihat dari bentuknya ada tiga jenis media massa, yakni media cetak, media penyiaran, dan media online / internet. Perkembangan teknologi ini tidak bisa lepas dari apa yang kita kenal dengan Internet. Internet merupakan singkatan dari Interconnection Networking. Secara sederhana, internet bisa diartikan sebuah jaringan global dari sebuah jaringan komputer. Jaringan internet sukses ikembangkan dan diujicobakan pertama kali pada tahun 1969 oleh US Departement of Defense dalam proye ARPANet (Advanced Research Project Network). Semenjak itu perkembangan internet berlangsung sangat pesat. Roida Pakpahan, Analisis Fenomena Hoax Diberbagai Media Sosial Dan Cara Menanggulangi Hoax, Konferensi Nasional Ilmu $\begin{array}{lll}\text { Sosial } \quad \text { \&Teknologi media } & \text { (KNiST), }\end{array}$ 
online_58e41fe67597732a41 ebff88 diakses jam 10.00 wib tgl 08-01-2018 Akhir-akhir ini sedang mencuat kasus penistaan agama yang dilakukan oleh Basuki Tjahaja Purnama atau yang akrab dipanggil Ahok. Banyak berita yang muncul di media mengenai kasus ini. Namun berita yang muncul tidak semua sesuai dengan fakta yang sebenarnya atau yang sering disebut dengan berita Hoax. Istilah hoax atau berita bohong saat ini mungkin tidak asing lagi di telinga kita. Saat ini hampir setiap saat kita mendengar kata tersebut entah itu di televisi, radio, surat kabar, dan yang paling sering media sosial. Sebenarnya berita Hoax tidak hanya beredar di media online saja. Berita hoax juga sempat beredar di media cetak, yaitu pada pemberitaan Presiden Jokowi pada saat pemilu tahun 2014. Di edisi pertama tanggal 5-11 Mei 2014, tabloid tersebut membuat tulisan yang dari judulnya saja tampak menghina Jokowi. Judul itu diantaranya Capres Boneka, Jokowi Anak Tionghoa, Putra Cina asal Solo, Ayah Jokowi adalah Oey Hong Liong, Status Perkawinan ibunda Jokowi dengan Pey Hong Liong?, Dalam Tradisi Cina Kaya, Wanita Pribumi Hanya Akan Dijadikan Gundik, atau Nyai, Sebagai anak gundik, Jokowi tak berhak menyandang nama marga (Tse) Oey, Cukong-Cukong di Belakang Jokowi, Dari Solo Sampai Jakarta De Islamisasi Ala Jokowi, Jokowi Guru Selamat yang Gagal, Sang Pendusta Mau Dibohongi Lagi, Capres Boneka Suka Ingkar Janji, Disandera Cukong dan Misionaris, serta Partai Salib Pendukung Jokowi.

Dalam Lintasan Sejarah Islam, Hoax pernah terjadi dalam banyak peristiwa, antara lain: Pada akhir 1980-an, pernah beredar surat berantai yang diklaim berasal dari si penjaga makam Nabi Shallalahu Alaihi Wasallam. Isinya memperingatkan Muslimin yang menerima selebaran itu agar menyalin dan membaginya ke 10 orang lain. Di era demokrasi sekarang ini, banyak hoax di medsos, mengancam pilar persatuan dan kerukunan umat. Bahkan The Arab Spring; الثورات العربيـة , demo, perang saudara, dan pertumpahan darah yang berujung tumbangnya beberapa negara di kawasan Timur Tengah, adalah (diduga) akibat virus hoax yang disebarkan melalui medsos. 


\section{Hoax Dalam Al-Qur'an}

Al-Qur'an menyebut hoax, antara lain berikut ini:

1. Hadist al-Ifki (Berita Bohong). Misalnya diketemukan dalam QS. Al-Nur (24) ayat 11-12, sebagai berikut:

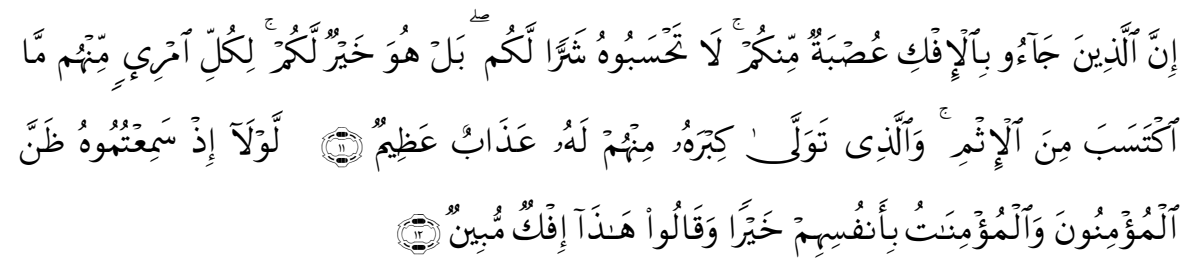

Artinya: "Sesungguhnya orang-orang yang membawa berita bohong itu adalah dari golongan kamu juga. Janganlah kamu kira bahwa berita bohong itu buruk bagi kamu bahkan ia adalah baik bagi kamu. Dan (mengapa tidak) berkata: "Ini adalah suatu berita bohong yang nyata."

2. "Faahisyah" (Berita Keji), sesuatu yang teramat keji, bahkan, terbilang dosa besar. Misalnya diketemukan dalam QS. Al-Nur (24) ayat 19:

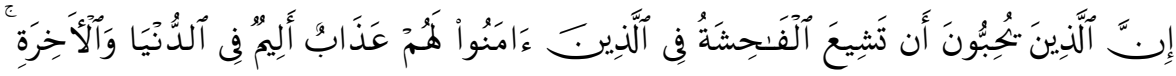

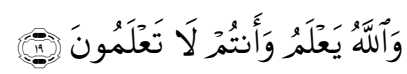

Artinya: "Sesungguhnya orang-orang yang ingin agar (berita) perbuatan yang amat keji itu tersiar di kalangan orang-orang yang beriman, bagi mereka azab yang pedih di dunia dan di akhirat. Dan Allah mengetahui, sedang, kamu tidak mengetahui."

3. Qaul al-Zuur (Perkataan Dusta). Misalnya Firman Allah SWT dalam QS. Al-Hajj (22) ayat 30, di mana dalam ayat ini Allah menggandengkan dua larangan; .........

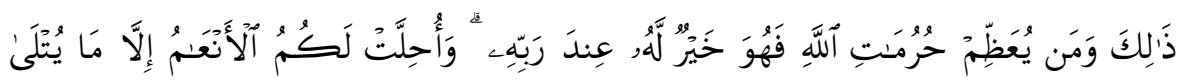

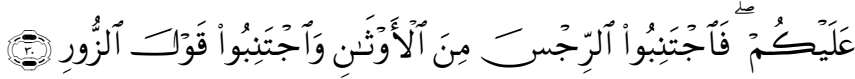


Artinya: ".....maka jauhilah olehmu (penyembahan) berhalaberhala yang najis itu dan jauhilah perkataan dusta."

\section{Hoax Dalam Al-Hadis}

Selain terdapat dalam Al-Qur'an, ancaman akibat menyebarkan hoax itu juga dinyatakan Nabi Shallalahu Alaihi Wasallam, misalnya tergambar dalam beberapa riwayat hadis sebagai berikut :

\section{Hadis Riwayat Al-Bukhari}

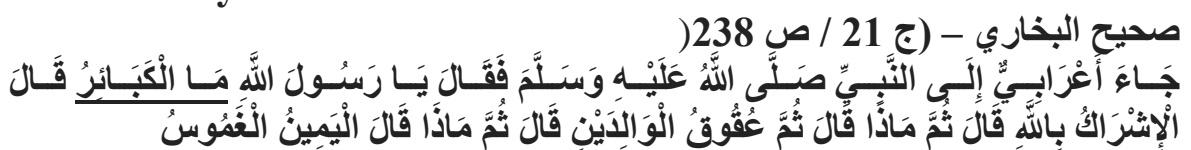
Artinya: Apa yang dikategorikan dosa besar? Nabi saw menjawab, "Mempersekutukan Allah, durhaka pada kedua orang tua, dan perkataan (persaksian) dusta (/palsu).

\section{Hadis Riwayat Imam Muslim}

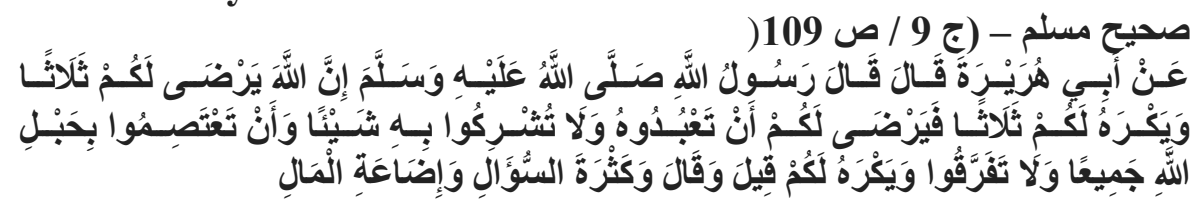
Artinya; "Sesungguhnya Allah meridhai bagi kalian tiga perkara dan membenci kalian tiga perkara. Dia meridhai kalian agar beribadah kepada-Nya dan tidak mempersekutuka-Nya dengan sesuatu pun, kalian berpegang teguh dengan tali Allah, dan agar kalian tidak berpecah belah. Dan dia membenci bagi kalian qiila wa qaala, banyak bertanya, dan membuang-buang harta."

Di antara deretan kalimat di atas, ada satu istilah yang mungkin perlu penjelasan tersendiri. Yakni, kata qiila wa qaala. Karena itu, beberapa ulama memberikan keterangan khusus istilah itu dalam hadis tersebut. Imam Al-Nawawi dalam kitabnya, "Syarah Shahih Muslim" mendefinisikan qiila wa qaala sebagai berikut; turut campur dalam kabar orang 
lain, menyampaikan informasi yang tidak diketahui sendiri, dan menceritakan semua yang didengar tanpa klarifikasi terlebih dulu. Secara teknis, istilah itu dapat diartikan mengabarkan informasi tanpa verifikasi atau menyebarkan desas-desus yang sumir. Pada akhir penjelasannya, Imam AlNawawi menambahkan peringatan dari hadis sebagai berikut:

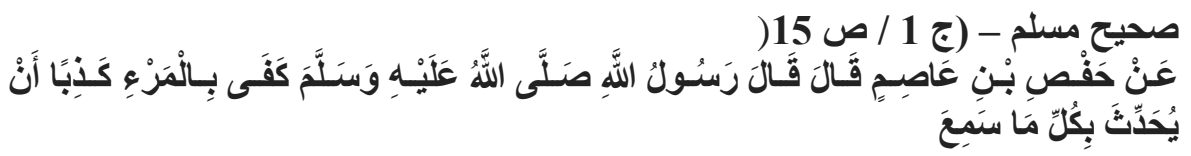

Artinya: "Cukuplah seseorang dikatakan pendusta tatkala menceritakan semua yang ia dengarkan.(tanpa klarifikasi).,

Perlu arahan, bimbingan, dan regulasi yang pasti, agar umat Islam dan rakyat Indonesia cerdas dalam bermedsos, terutama menerima dan menyebarkan berita atau informasi dari sumber yang tidak jelas kredibilitasnya. Umat Islam perlu didorong untuk membiasakan diri melakukan klarifikasi terhadap semua berita atau informasi. Apalagi kalau informasi itu datangnya dari orang-orangfasiq, wajib klarifikasi dan uji telaah akurasi dan validitas berita. Allah mengingatkan dalam firman-Nya, Q.S. Al-Hujurat (49) ayat 6, sebagai berikut :

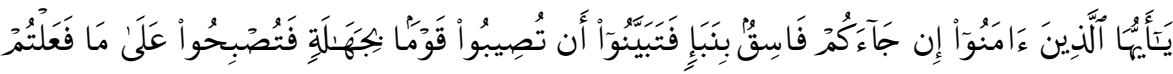

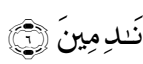

Artinya: "Hai orang-orang yang beriman, jika datang kepadamu orang fasik membawa suatu berita, maka periksalah dengan teliti agar kamu tidak menimpakan suatu musibah kepada suatu kaum tanpa mengetahui keadaannya yang menyebabkan kamu menyesal atas perbuatanmu."

Dampak hoax pertama, Generasi muda bisa tersita waktunya. Menteri Komunikasi dan Informatika, Rudiantara mengatakan bahwa berita hoax di media sosial bisa berdampak buruk bagi generasi muda. Produktivitas anak muda bisa tersita karena seringnya menggunakan media sosial. "jangan sampai perhatian kita terhadap keluarga dan orang sekitar menjadi berkurang" kata Rudiantara sebagaimana dikutip brilio.net dari laman Kominfo. Dedi Rianto Rahadi, perilaku penggunaan dan informasi hoax di media social, jurmal 
manajemen \& kewiraushaan vol 5 no 12017 (MALANG: JMDK, 2017) HAL 62 Sebuah studi dari Universitas Stanford menunjukkan anak muda terutama remaja atau mahasiswa menilai kebenaran berita dari detail konten seperti jumlah dan besarnya foto, panjang artikel, dan lain lain. Penelitian ini dilakukan kepada 7.840 siswa dari berbagai latar belakang. Responden diminta untuk memberikan evaluasi terhadap konten berita yang ditujukan. Hasil dari penelitian tersebut menyatakan bahwa anak muda lebih memprioritaskan isi artikel daripada sumber berita. Hal ini menjadi alasan kenapa anak muda sangat rentang sekali dengan berita hoax. Kedua, Memicu perpecahan. Berita hoax seringkali bermuatan isu SARA. Kelompok Saracen juga bermain di tema ini. Mereka bisa menyebarkan konten-konten bernada SARA. Alhasil, masyarakat akan terpecah belah karenanya. Masyarakat tidak bisa membedakan isu mana yang benar dan hoax. Menteri Agama Lukman Hakim Saifuddin pernah mengatakan bahwa persatuan Indonesia tidak boleh goyah hanya karena provokasi dan hasutan. Ketiga, Menurunkan reputasi pihak yang dirugikan. Berita hoax seringkali menjatuhkan pihak tertentu. Dengan banyaknya berita hoax, pihak yang dirugikan akan kesulitan untuk melakukan klarifikasii Kemendikbud dari twitternya @Kemendikbud mengatakan bahwa pelaku kejahatan bisa menurunkan status sosial dari objek berita hoax tersebut. Berita hoax juga bisa digunakan untuk mengalahkan kelompok tertentu dalam politik seperti pada saat Pilkada. Penelitian yang dilakukan oleh Hunt Allcott menunjukkan fakta bahwa orang dewasa AS membaca dan mengingat satu atau beberapa artikel berita bohong pada saat periode kampanye. Berita bohong ternyata mempunyai efek besar dalam pemilihan tersebut dan mampu mempengaruhi suara yang didapatkan oleh kandidat presiden. Keempat, Menguntungkan pihak tertentu. Kasus kelompok pembuat berita profesional Saracen merupakan bukti nyata bahwa bisnis hoax menggiurkan. Motif ekonomi bisa menjadi alasan penyebaran berita hoax. Dilansir dari merdeka.com, Kasubag Ops Satgas Patroli Siber Bareskrim Polri AKBP Susatyo Purnomo mengatakan bahwa nominal yang diterima oleh kelompok ini bisa mencapai Rp 100 juta setiap proyek. 
Kelima, Berita hoax membuat fakta tidak lagi bisa dipercaya. Dengan semakin viralnya berita hoax, fakta sebenarnya malah bisa dicap sebagai berita hoax. Dengan ini masyarakat bisa kebingungan tentang fakta mana yang harus dipercaya. Dilansir dari website resmi kominfo, Juru Bicara Presiden Johan Budi menegaskan bahwa berita bohong harus dilawan. "Fungsi humas adalah merespons tuduhan atau finah tak benar," ujarnya. Johan juga berpesan agar komunikasi dilakukan dengan tepat dan jelas. Berita hoax bisa muncul dari komunikasi yang kurang tepat dan bisa membuat persepsi masyarakat menjadi buruk.11 11 https: //www. brilio.net /serius/ hoax- dan- ujaran- kebencian- jadi- bisnis- ini- 5dampak-paling mengerikan-170825g. html diakses jam 19.45 wib tgl 12-01-2018

Hoax dalam Al-Quran direpresentasikan dengan istilah ifk, fasiq, munafiq, murjifun, dan tabayyun. Setelah melakukan pembacaan atas ayat-ayat yang berkaitan dengan istilah tersebut, disimpulkan bahwa berita hoax dapat diminimalisir dengan cara berpikir kritis, memiliki kematangan emosi, melakukan tabayyun, dan memperluas wawasan. Selain itu, Al-Quran juga mengajarkan etika berkomunikasi yang baik, yaitu qaulan sadidan (tutur kata yang benar), qaulan baligan (perkataan baik yang membekas pada jiwa), qaulan maisuran (ucapan yang pantas), qaulan layyinan (kata-kata yang lemah lembut), qaulan kariman (perkataan yang mulia), dan qaulan ma'rufan (perkataan yang baik). Sebagai Muslim yang baik hendaknya selektif dan kritis dalam menanggapi berita-berita yang tersebar di sosial media. Karena hal tersebut menentukan akan mendapat dampak positif atau dampak negatif. Apabila mendapat dampak positif, maka sosial media akan menjadi sangat berguna bagi penerima dan penikmat beritaberita yang beredar. Sebaliknya, apabila mendapat dampak negatif, maka sosial media hanya akan menjadi penipu bisu baginya, lantaran sosial media tidak bisa mengklarifikasi berita tanpa seseorang yang mencari kebenarannya sendi.

Hoax adalah suatu kata yang digunakan untuk menunjukan pemberitaan palsu atau usaha untuk menipu atau mengakali pembaca/pendengarnya untuk mempercayai sesuatu 
yang biasanya digunakan dalam medos, misalnya: facebook, tweeter, blog, dan lain-lain.

Prinsip-prinsip komnikasi Islam dalam memerangi HOAX. Harjani haefni (2019:259) menjelaskan secara umum sembilan prinsip melawan hoax dalam ajaran Islam.

1. Prinsip Ikhlas; prinsip yang paling mendasar dalam komunikasi Islam dengan prinsip ini komunikasi menjadi berpahala.

2. Prinsip pahala dan dosa: prinsip ini menjelaskan bahwa setiap pesan atau pernyataan yang keluar itu mengandung konsekwensi pahala dan dosa;

a. Melarang menulis dan berkata-kata yang bernuansa kasar, hasud, kotor dan sejenis.

b. Memberi motivasi agar menyampaikan pesan yang baik.

c. Berkata yang baik menyebabkan masuk surga.

d. Berkata baik sebagai sodaqoh.

e. Islam identik dengan kebaikan.

3. Prinsip kejujuran: kejujuran dalam menyampaikan pesan merupakan prinsip dasar dalam komunikasi Islam.

4. Prinsip berkata positif; pesan positif sangat berpengaruh bagi kebahagiaan seseorang. Pesan positif diungkap melalui bahasa optimistis.

5. Prinsip dua telinga satu mulut: menerima informasi sebanyakbanyaknya, kemudian memfilternya, mengambil dan menyampaikan yang baik-baik dan bermanfaat untuk orang banyak.

6. Prinsip pengawasan: prinsip ini muncul dari kepercayaan mukmin yang meyakini bahwa Allah Maha Mendengar, Maha melihat dan Maha Mengetahui..

7. Prinsip selektif dan validitas. Berbicara dengan data dan informasi yang akurat.

8. Prinsip keseimbangan dan keadilan; upaya untuk mencari informasi, tidak hanya dari pembuat berita tetapi juga dari sumber berita.

\section{Simpulan}

Berita hoax yang sulit dikontrol saat ini memerlukan intervensi agama dalam penanganannya. Islam sangat konsen dengan pemberantasan berita hoax. Kalau akhlak berkomunikasi dibangun dengan prinsip-prinsip keikhlasan, kejujuran, pengawasan, 
124 Takdir Alisyahbana, Hoax Dalam Perspektif Islam ,.....

keseimbangan dan keadilan sebagai yang diajarkan oleh Islam, maka perlawanan terhadap berita Hoax akan dapat dimenangkan oleh kebenaran. 


\section{DAFTAR PUSTAKA}

AEP Wahyudin dan manik Sunuantari editor, Melawan HOAX, trast Media, Yogyakarta, 2019.

https://www.brilio.net/serius/hoax-dan-ujaran-kebencian-jadi-bisnisini-5-dampak-palingmengerikan-170825g.html diakses jam 19.45 wib tgl 12-01-2018

Jurmal manajemen \& kewiraushaan vol 5 no 12017 (MALANG: JMDK, 2017) http://www.kompasiana.com/bayusuardiputra/fenomena-hoaxpada mediaonline_58e41fe67597732a41ebff88 diakses jam 10.00 wib tgl 08-01-2018

Muhammad bin Ismail Abu Abdillah al-Bukhari al-Jufi, Shahih Bukhari, Dar Thaq al-Najah 1422 